\title{
THE DUTY OF AN INSURER TO ACT PROMPTLY ON APPLICATIONS
}

The making of a coritract of insurance is not always a simple matter. In many instances, of course, the person seeking insurance is dealing face to face with an authorized agent of the insurance company, who has power to bind his principal by issuing to the applicant a policy properly countersigned by him. In many other instances, however, especially in the field of life insurance, the applicant has personal dealings with an agent of the company who is athorized only to solicit applications, and to transmit them to some superior agent, or to the home office of his principal. This type of instiratice agent has no power to bind the company to contracts of insurance. ${ }^{1} \mathrm{He}$ can not accept or reject applications. He is merely a conduit, through which the application, in the eyes of the law an offer on the part of the applicant to enter into a contract of insurance with the company, must pass, on its journey to the person or persons in whom is vested the power to decide what contracts the insurance company shall make. Before this decision is made, certain other steps are sometimes necessary. For example, the applicant for a policy of life insurance is usually required to undergo a physical examination, a report of which is forwarded to the home office along with the application itself, and is there carefully considered.

In the ordinary course of events, the machinery which carries the application to the company, and the subsequently issued policy back to the applicant, functions properly. But there are occasions when it does not do so. It has happened not infrequently that carelessness somewhere along the road has caused delay in the issuing and delivery of the policy, and that the contingency which the applicant sought to insure against has occurred after the time when the policy normally would have been issued. The applicant, in such a situation, has very naturally felt himself aggrieved by the conduct of the insurance company. If the latter had acted promptly, the applicant would probably have

${ }^{1}$ Richards, Insurance Law (3d ed., I909) § I65. 
been reimbursed for his loss: for had it accepted the application, it would have been liable to him on the policy of insurance; while had it rejected the proposal, the applicant might well have procured protection elsewhere. The applicant, therefore, has, in a number of instances, sought to subject the insurance company to some form of legal liability. The treatment which courts have accorded to the disappointed applicant has been somewhat varied, but in recent years the tendency has been to allow him to recover from the company damages for the latter's failure to accept or reject promptly his application. This has caused an outcry on the part of at least one writer, who maintains that the modern cases are ill-considered, "newfangled," and unjust. ${ }^{2}$ An examination of the decisions dealing with the problem shows that the second criticism, at least, is unmerited; that for a hundred years the disappointed applicant has been maintaining actions against the insurance company; that his right to recover has always been arguable; and that he has at all times had the sympathy of the courts. During the last fifteen years his litigation has been on the whole most successful, but even before that time, he won sporadic victories.

In the beginning, the applicant sued the insurance company in an action of contract. This proved to be not a very happy remedy. In a few cases the applicant was allowed to recover, on the ground that the agent of the defendant was authorized to make, and did make, a binding contract of insurance, reserving to his principal, however, a power to repudiate the agreement if, before any loss occurred, it should decide that the risk was an undesirable one. ${ }^{3}$ Inasmuch as this power had not been exercised by the defendant at the time when the contingency insured against had happened, the defendant was liable on the contract. Some of these decisions are open to serious question, because it is by no means clear that the agent had authority to make such a contract,

2 James C. Jones, Tort or No Tort, 56 CHr. LEG. N. 366 (I924).

${ }^{3}$ Insurance Co. v. Webster, 6 Wall. I29 (U. S., I867); Continental Ins. Co. v. Haines, Io Ky. L. R. 276 ( I888); Halle v. New York Life Ins. Co., 22 Ky. L. R 740 (I900); Perkins v. Washington Ins. Co., 4 Cow. 645 (N. Y., I825); Palm, Adm'r. v. Medina County. Mutual Fire Ins. Co., 20 Ohio, 529 (I85I). 
or that he actually did make it. ${ }^{4}$ Such an agreement has been implied from the practice of the company in giving to policies when they were issued the date borne by the application, even in the face of the provision "and it is understood and agreed that the insurance hereby applied for shall not be binding until so approved." 5 However, in a number of other decisions, the company had followed a similar practice, yet the courts refused to hold that any preliminary agreement existed. ${ }^{6}$ This custom of giving the policy the same date as the application creates a peculiar dilemma. In all the cases just cited, the appellant was paying a premium for a certain period, $i . e$. , from the date of the application to the expiration of the insurance; but was receiving protection only during a shorter period, $i$. e., from the issuing of the policy to the expiration of the insurance. While his application was being considered, he was paying a premium and receiving nothing. On the other hand, if a court implies an agreement that the applicant has insurance until his proposal is rejected, he may be receiving protection without payment, since if his application is refused, the company will return his entire premium. It is believed that the parties do not intend, in the ordinary instance, to make a preliminary contract, and that the company should not be liable for a loss which occurs before it has approved the proposal. A feeling of sympathy on the part of the court for the plaintiff whose property had been destroyed is perhaps responsible for the implication of an agreement which neither the agent nor the applicant was in the least conscious of making.

In the majority of cases, however, the plaintiff maintained his action on the theory that the long silence of the insurance com-

4Palm, Adm'r. v. Medina County Mutual Fire Ins. Co., supra, note 3, for example, was reversed on another point, and was criticised, in 5 Ohio, I07 (1855); but it was subsequently cited with approval in Kremm v. Jefferson Fire Ins. Co., 40 Ohio, 225 (1883).

${ }^{5}$ Continental Insurance Co. v. Haynes, supra, note 3 ; and see also Trask v. German Insurance Co., 53 Mo. App. 625 (1893).

- Alabama Gold Life Ins. Co. v. Mayes, 61 Ala. I63 (1878) ; Pickett v. German Fire Ins. Co., 39 Kan. 697, I8 Pac. 903 (1888); Northwestern Mutuai Life Ins. Co. v. Neafus, I45 Ky. 563 , I40 S. W. I026 (I9II); More v. New York Bowery Fire Ins. Co., I30 N. Y. 537, 29 N. E. 757 (I892); Shawnee Mutual Fire Ins. Co. v. McClure, 39 Okla. 535, I35 Pac. 1150 (I9I3); Connecticut Mutual Ins. Co. v. Rudolph, 45 Tex. 454 (I876). 
pany constituted an acceptance of the offer contained in his application, or that from the silence the law would presume an acceptance. The argument of the plaintiff here has not prevailed in courts of last resort. On the contrary, there have been many decisions, ${ }^{7}$ and many dicta, ${ }^{8}$ that silence or delay could in no instance be tantamount to an acceptance, and that the court would not indulge in any such unnatural presumption as that contended for. A number of opinions pointed out that the normal inference to be drawn from the failure of the company to tell the applicant that his offer has been accepted is that for some reason the company has seen fit to question the desirability of the risk, and has either rejected the application or is holding it for subsequent action. ${ }^{9}$ In the great majority of cases where the suit has been

${ }^{7}$ Misselhorn v. Mutual Reserve Fund Life Assn., 30 Fed. 545 (C. C. Mo., I887) ; Alabama Gold Life Ins. Co. v. Mayes, supra, note 6; Stewart v. Helvetia Swiss Fire Ins. Co., I02 Cal. 218, 36 Pac. 4I0 (1894); Live Stock Ins. Co. v. Stickler, 75 Ind. App. I9I, II5 N. E. 69I (I9I6); Walker v. Farmers Ins. Co., $5 I$ Iowa, 679 ( I879); Atkinson v. Hawkeye Ins. Co., 71 Iowa, 340, 32 N. W. 37 I ( 887 ) ; Trask v. German Ins. Co., supra, note 5 ; St. Paul Fire and Marine Ins. Co. v. Kelley et al., 2 Neb. Unoff. 720,89 N. W. 997 (I902); Handlier v. Knights of Columbus, 106 Neb. 267,183 N. W. 302 (I92I); More v. N. Y. Bowery Fire Ins. Co., supra, note 6; Ross v. N. Y. Life Ins. Co., 124 N. C. 395, 32 S. E. 733 (1899); Home Forum Benefit Order v. Jones, 5 Okla. 598, 50 Pac I65 (1897) ; Dorman v. Connecticut Fire Ins. Co., 4I Okla. 509, I37 Pac. 262 (Igr4) ; Insurance Co. v. Johnson, $23 \mathrm{~Pa} .72$ (1854); Royal Ins. Co. v. Beatty, II9 Pa. 6, I2 Atl. 607 (I888); Brink v. Merchants \& Farmers United Mutual Ins. Assn., I7 S. D. 235, 95 N. W. 929 (I903); McLendon v. Woodmen of the World, I06 Tenn. 695, 64 S. W. 36 (I90I); Northern Neck Mut. Fire Assn. v. Turlington, 136 Va. 44, II6 S. E. 363 (I923); Haden v. Farmers \& Merchants Fire Assn., 80 Va. 683 (I885).

In the following cases, the defendant company was able to show that there had been no unreasonable delay: Steinle v. N. Y. Life Ins. Co., 81 Fed. 489 (C. C. A. 5th, I897); Winnesheik Ins. Co. v. Holzgrafe, 53 Ill. 516 (1870); Pickett v. German Fire Ins. Co., supra, note 6 ; Harp v. Grangers Mutual Fire Ins. Co., 49 Md. 307 (1878); Shawnee Mutual Fire Ins. Co. v. McClure, supra, note 6; Ripka v. Mutual Fire Ins. Co. of Annville, $36 \mathrm{~Pa}$. Super. 5 I7 (I908).

${ }^{3}$ Kohen v. Mutual Reserve Fund Life Assn., 28 Fed. 705 (C. C. Mo., I886); Equitable Life Ass. Soc. v. McElroy, 83 Fed. 63 I (C. C. A. 8th, I897); Heiman v. Phoenix Mutual Life Ins. Co., I7 Minn. I53 (1871); Haskin v. Agricultural Fire Ins. Co., 78 Va. 700 (1894).

- See especially Johnson v. Insurance Co.; Ross v. N. Y. Life Ins. Co.; Brink v. Merchants \& Farmers United Mut. Ins. Asso., all supra, note 7 .

In the converse situation, where the company sued the applicant on the note which he gave for the premium, and the latter defended on the ground of failure of consideration, in that no policy had been issued, the courts have held the defense valid, and have refused to decide that the silence of the plaintiff constituted an acceptance of the defendant's offer. Home Ins. Co. v. Swan, 34 Ga. App. 19, 128 S. E. 70 (r925); Van Arsdale \& Osborne v. Young, 21 Okla. I5I, 95 Pac. 778 (1908). 
upon the contract, recovery has been denied the plaintiff. There are only a few isolated decisions where he has been successful in such an action. ${ }^{10}$

One surprising feature which must strike anyone who. makes a careful examination of the decisions is the number of times the plaintiff has secured a judgment in the court below. In a large number of decisions cited in the preceding paragraph, the appellate court was compelled to reverse the trial court. ${ }^{11}$ Why courts of original jurisdiction should so repeatedly act in opposition to the established weight of authority and to the ordinarily accepted theory of the law of contract is difficult to understand. It would seem to indicate a strong feeling on the part of judges that in this situation the plaintiff should have relief, that the insurance company had been guilty of misconduct for which it should be forced to respond in damages. Even justices of the courts of appeal seem to share this attitude, for a number of opinions which deny the plaintiff recovery, suggest that the insurance company might be liable in some other form of action. ${ }^{12}$

One case has held the company liable on a theory of estoppel, because the company by its silence led the plaintiff's intestate to believe that his application had been accepted. Great Southern Life Ins. Co. v. Dolan, 239 S. W. 236 (Tex. Civ. App., 1922). This was reversed, 262 S. W. 475 (Tex., 1924), because the plaintiff had declared not on the completed agreement, but on a preliminary contract which it was alleged the defendant's agent had made, and as to which there was no evidence. See also Gonsoulin v. Equitable Life Ass. Co., I52 La. 865, 94 So. 424 (1922).

${ }^{10}$ Somerset County Mutual Fire Ins. Co. v. May, Ex'r., 2 W. N. C. 43 (Pa., 1875) (the Supreme Court of Pennsylvania being equally divided, affirmed the judgment of the Court of Common Pleas of Somerset County) ; Preferred Accident Ins. Co. v. Stone, 6I Kan. 48, 58 Pac. 986 (1899) ; Stearns v. Merchants Life and Casualty Co., 38 N. D. 524, 165 N. W. 568 (1917). See also dictum in Robinson v. U. S. Benevolent So., 132 Mich. 695, 94 N. W. 21 I (1903). And $c f$. Cole-McIntyre-Norfleet Co. v. Holloway, I4I Tenn. 879, 214 S. W. 817 (I9r9), a case dealing with the acceptance of an order for the sale of goods.

"Alabama Gold Life Ins. Co. v. Mayes; Stewart v. Helvetia Swiss Fire Ins. Co.; Livestock Ins. Co. v. Stickler; Walker v. Farmers Ins. Co.; Trask v. German Ins. Co.; St. Paul Fire \& Marine Ins. Co. v. Kelly et al.; More v. New York Bowery Fire Ins. Co.; Home Forum Benefit Order v. Jones; Royal Ins. Co. v. Beatty; Haden v. Farmers \& Mechanics Fire Assn.; Winnesheik Ins. Co. v. Holzgrafe; Shawnee Mut. Fire Ins. Co. v. McClure; Ripka v. Mutual Fire Ins. Co., all supra, note 7 ; Connecticut Mutual L. I. Co. v. Rudolph; Northwestern Mutual Life Ins. Co. v. Neafus, supra, note 6.

${ }^{12}$ It was suggested many years ago that the company might be liable for the negligence of its agents; this seems to foreshadow the doctrine of tort liability to be discussed later. Walker v. Farmers Ins. Co.; Haden v. Farmers \& Mechanics Fire Assn., supra, note 7; see also Stewart v. Helvetia Swiss Fire Ins. Co., supra, note 7 , and Perkins v. Washington Ins. Co, supra, note 3 (opinion of 
Finally a plaintiff adopted a new course. One Carter, a resident of the Hawaiian Islands, made an application to the defendant for a policy of life insurance. Due to certain mistakes of the physician who conducted the physical examination, and also to the action of the defendant's agent, prompted by a desire to send in a number of applications at one time, in retaining Carter's proposal for an undue period, no policy had been issued at the time when Carter was killed. Carter was a desirable risk, and had the agent forwarded the application immediately, there is no question that it would have been accepted. The executors of Carter brought an action in tort against the company, and obtained a verdict. The defendant appealed, alleging as error the failure of the trial court to grant its request for a nonsuit, and judgment for the plaintiff was affirmed. ${ }^{13}$ The court held that the agent of the defendant was under a non-contractual duty to forward the application promptly, and that for his breach of the duty the company was liable. It also suggested that there may have been either an express or an implied promise to forward the proposal, the consideration for which was the making of the application, the submission to the physical examination, and the depositing of a promissory note to be used in payment of the first premium if the application should be accepted. The court admitted that the problem before it was entirely a new one, on which it could find no cases directly in point. ${ }^{14}$ It specifically refused to say whether it would have reached the same result had the agent immediately

Colden, Sen.), where the view is expressed that the agent, if sued, would be liable for his carclessness. The writers of these opinions must have believed that the agent was under a legal duty to act promptly.

There are also dicta that long delay might, under some circumstances, constitute an acceptance, or raise a presumption of acceptance. Winnesheik Ins. Co. v. Holzgrafe; Atkinson v. Hawkeye Ins. Co.; Pickett v. German Fire Ins. Co., all supra, note 7 .

The statement of Justice Brewer in Misselhorn v. Mutual Reserve Fund Life Assn., supra, note 7, that the receipt of the application might cast on the company a moral duty to act promptly is significant. It is not a very great transition from a moral duty, i. e., one which an individual cannot be penalized for failing to perform, but which all persons believe he should perform, to a legal duty, for breach of which he is liable in damages.

${ }^{13}$ Carter v. Manhattan Life Ins. Co., Ir Hawaiian Rep. 69 (I897).

14 The court cited Stewart v. Helvetia Swiss Ins. Co., Trask v. German Ins. Co.; Walker v. Farmers Ins. Co., all supra, note 7 ; Perkins v. Washington Ins. Co., supra, note 3 ; Greenwich Ins. Co. v. Waterman, 54 Fed. 839 (C. C. A. 6 th, 1893) ; State Ins. Co. v. Jamieson, 79 Iowa, 245, 44 N. W. 37 I (I890). 
forwarded the application, and the failure of the company to issue the policy been the result of carelessness occurring in its - own home office, or of a deliberate refusal to pass upon the application.

This decision excited no comment whatever. It is doubtful whether more than a very few members of the bar in the United States knew of its existence. Fifteen years elapsed before another case like it arose, during which time disappointed applicants continued their unsuccessful attempts to hold the insurance company liable in an action of contract. ${ }^{15}$ When finally a suit was brought in tort, the Hawaiian decision was neither argued by counsel nor cited by the court.

Boyer v. State Farmers' Mutual Hail Insurance Company ${ }^{16}$ really marks the beginning of the doctrine that an insurance company is liable for the carelessness of its agents and servants in forwarding the application or issuing the policy. Here an agent held the plaintiff's application for hail insurance three days before he forwarded it, with the result that when the plaintiff's crops were destroyed, no policy had been issued. The trial court found the facts and gave judgment for the plaintiff, which was affirmed on appeal by Judge Burch. His opinion is short and fails to state the reason for the existence of the obligation to forward the application. He says that "there was sufficient danger to the plaintiff to be apprehended from delay in closing the transaction that a reasonably prudent business man, guided by the considerations which ordinarily regulate conduct, would have acted with diligence." $\mathrm{He}$ assumes that the agent himself would be liable for his neglect, and hence deduces that the defendant, the agent's principal, is likewise liable.

In a sense, the judge is begging the question. His assumption that the agent would be liable to the plaintiff cannot be granted without argument. The only reason suggested for imposing such an obligation is that a prudent business man would have forwarded the policy. Because the agent did not live up to

\footnotetext{
${ }^{15}$ See cases cited, supra.

${ }^{20} 86$ Kan. 442, 121 Pac. 329 (1912).
} 
the ideal which existed in the mind of the court, he is held legally liable.

No one will question that the agent acted improperly in retaining the application. But that alone is not a satisfactory reason for holding that he has committed a tort. Many persons fail to exercise the diligence of a prudent business man, guided by the consideration which ordinarily regulates conduct, without rendering themselves liable to those who suffer because of their lack of care. The law does not impose on persons in general a duty to act to save others from harm. It is only in certain specific situations where a man is under affirmative obligations. It may well be that the interests of society demand that a duty be imposed on the agent in a case like that before the Kansas court. Certainly the court must have felt so. But it is unfortunate that the writer of the opinion did not state the considerations which compelled him to create this new doctrine. The brevity with which he treats the problem and the failure to explain adequately his reasons for adopting the rule announced are matters of regret.

In the following year, the legislature of North Dakota passed a statute, substantially enacting the rule of the Boyer case. ${ }^{17}$ It required any company engaged in the business of writing hail insurance within the state to notify an applicant of the rejection of his application within twenty-four hours of the time it was received. If the company failed to do so, a contract of insurance came into effect. When the validity of this statute was attacked, the Supreme Court of North Dakota held it to be a reasonable regulation, made in the interest of the public, which was necessary to protect the economic welfare of the state's agricultural population; and one with which it was possible for the insurance companies, by somewhat altering their methods of doing business, to comply. ${ }^{18}$ The Federal Supreme Court, while stating that the wisdom of the statute was not for it to consider, likewise held that the law did not transcend the limit of the state's power to $\S 4902$.

${ }^{17}$ Laws, N. D., 1913, c. 177, No. I; N. Dak. Comp. Laws, Ann. (1913)

${ }^{18}$ Wanberg v. National Union Fire Ins. Co., 46 N. D. 369 , I79 N. W. 660 (1920). Robinson, J., dissented. 
regulate insurance companies in order to promote the public welfare. ${ }^{19}$ The North Dakota statute is another manifestation of the feeling which has been commented on before, that an insurance company should be required to exercise care in dealing expeditiously with the applications which it receives, and that where a loss occurs against which the applicant might have been protected had it disposed of the application with greater speed, the burden of that loss should be upon it, rather than upon the unfortunate individual.

In the same year, the Supreme Court of Iowa decided the case of Duffie v. Bankers Life Association, ${ }^{20}$ which has been cited more often than any other decision on the subject. Here the view was adopted that the company was under a duty to act promptly because it held a franchise from the state. This reason, of course, is weak, since every corporation holds a franchise, charter, etc., yet it would never be suggested that all corporations are under a duty to dispose promptly of all offers which they received. It may be that the court has in mind the fact that the business of insurance is so affected with the public interest that the state may regulate its conduct in many different ways. But again the answer may be made that there are other businesses, which can be just as highly supervised and regulated, but to which no such doctrine as the one adopted has ever been applied. In order to justify its position, the court should have demonstrated that certain peculiar characteristics of the insurance business make the imposition of such a duty essential to the public welfare; this it failed to do. The court is also influenced by the fact that the policy, if issued, would have been dated as of the day the application was signed, and that therefore the defendant would have received a premium for a period during which it was running no risk. This factor does seem important; the insurance company does occupy a strategic position, whereas the applicant is at a distinct disadvantage. One can readily understand the desire of the court that this period of suspense should not be prolonged unduly, and it seems probable that this

\footnotetext{
${ }^{20}$ National Ins. Co. v. Wanberg, 260 U. S. 7I (1922).

${ }^{20}$ I60 Iowa, 19, 139 N. W. 1087 (1913).
} 
element was largely responsible for the decision of the court that the insurance company must decide on the proposal within a reasonable time. As far as precedent is concerned, the court relies on the Boyer case, and on dicta found in some of the decisions where the action was brought on the alleged contract. ${ }^{21}$

Three years later, the Supreme Court of Nebraska, by a majority of one, adopted and applied the same rule in the case of Wilkin v. Capital Fire Insurance Co., ${ }^{22}$ entirely on the authority of the Duffie case, from which it quoted at great length. Subsequent decisions in Nebraska have not expressly repudiated this rule; but in two instances, recovery has been denied to the plaintiff on the ground that he has shown no negligence on the part of the defendant, and the language of the court has indicated a reluctance to apply the doctrine of the Wilkin case. ${ }^{23}$

The next tribunal to pass on the question was the Supreme Court of Arkansas, which decided that a verdict for the defendant should have been directed, on the ground that even if the agent had acted promptly, the company, under the terms of the application, would have been under no duty to issue a policy, and might have capriciously rejected the proposal. ${ }^{24}$ This undoubtedly begs the question. Although it has been suggested that an

${ }^{21}$ Northwestern Mutual Life Ins. Co. v. Neafus, supra, note 6; Continental Ins. Co. v. Haynes, supra, note 3 ; Walker v. Farmers Ins. Co., supra, note 7.

${ }^{23} 99$ Neb. 828, I57 N. W. I02I (I916).

${ }^{23}$ In Meyer v. Central States Life Ins. Co., I03 Neb. 640, I73 N. W. 578 (1919), the delay resulted because the examining physician used a faulty instrument which showed that the applicant had too high a blood pressure. The court held that there was no evidence of negligence for which the defendant was responsible - [a doubtful decision, for was not the physician the agent of the company? Cf. Dyer v. Missouri State Life Ins. Co., I32 Wash. 378, 232 Pac. 346 (r925) ] and then went on to say: "Without regard to the insufficiency of the evidence to sustain the judgment (for the plaintiff), it is the opinion of the writer that no cause of action exists in favor of the plaintiff and against the defendant." The opinion was written by Rose, $J$., who had dissented in the Wilkin case.

In Page v. National Automobile Ins. Co., rog Neb. 127, I90 N. W. 2I3 (I922), the Wilkin case was referred to by Rose, $J$., but he disclaimed passing on the question of whether any duty to act promptly on the application existed. The plaintiff's action was dismissed because of the insufficiency of the evidence to sustain the judgment. In Handlier v. Knights of Columbus, supra, note 7 , the plaintiff sued on the contract, and failed to recover.

${ }^{24}$ National Union Fire Ins. Co. v. School District No. 55, I22 Ark. 179, I82 S. W. 547 (1916). This case was cited as governing the question in Interstate Business Men's Accident Assn. v. Nichols, 143 Ark. 369, 220 S. W. 477 (1920). 
insurance company should be treated as a public servant under a duty to furnish its service by issuing its policy to any properly qualified applicant, ${ }^{25}$ this view has never been adopted by any court. $^{26}$ The judges who wrote the opinions in the four cases which adopted the rule requiring prompt action were under no illusions on this point. None of them suggested that the defendant was bound to accept the plaintiff's offer, and it is believed that all of them would have held it was not so bound. The North Dakota statute allowed to the insurance companies the privilege of rejecting applications for any cause whatever, provided they communicated their rejections to the applicants within the required time; and it is doubtful whether, if the statute had attempted to impose on the insurance companies a duty similar to that owed by carriers and other public servants, to serve all comers, it would have been held constitutional by the Supreme Court of the United States. ${ }^{27}$ The position taken by the courts following the Boyer and Duffie cases has been that, while the insurance company had an absolute privilege to accept or to reject, it must do one or the other within a reasonable time. To this, the argument of the Arkansas court is no answer.

That their opinion exerted no great influence on the minds of the judiciary in other states is shown by several decisions within the next three years, in which the plaintiff recovered. The Supreme Court of North Dakota held that the insurance company was liable even in a suit on the contract, on the ground that a preliminary agreement existed, whereby the contract of insurance was to come into existence if the company did not reject the application and return the deposit within a reasonable time. It also stated that it could see no real distinction between its decision, and those holding the company liable in tort for its neg-

\footnotetext{
${ }^{25}$ See Patterson, The Delivery of a Life Insurance Policy, 33 Harv. L. REv. 198, at pp. 216, 217 (I919).

* Of course, cases where a duly authorized agent of the insurance company has contracted that the applicant shall be insured from the moment he signs the application, unless the company shall, for some reasonable cause, repudiate the contract, stand on a different footing. See citations, supra.

${ }^{2} C f$. Opinion of Chief Justice Taft in National Union Fire Ins. Co. v. Wanberg, supra, note 19.
} 
ligence. ${ }^{28}$ Iowa reaffirmed the position which it had adopted in the Duffie case. ${ }^{29}$ Idaho, in which the question arose for the first time, held that both the company and the agent to whom the application was made were liable in tort where, because of the carelessness of the latter, no policy was issued. ${ }^{30}$ In this case the reasoning of the court is peculiar. It is found as a fact that the agent made a valid preliminary agreement to issue a policy of insurance to the plaintiff. The latter, therefore, had a right of action on this contract against the insurance company, but had none against the agent. ${ }^{31}$ The suit, however, was brought, not in contract, but in tort, for the negligence of the agent in failing to issue the policy, and both the company and the agent were named defendants. The court held that the conduct of the agent was a tort, a violation of a duty which arose because of the preliminary agreement, and that both parties defendant were liable. The question of whether a duty would exist in the absence of any preliminary agreement is left unanswered, although the Court cited the Boyer and Duffie cases with apparent approval. Yet this is really the chief issue involved. If such. a common-law ${ }^{32}$ duty to act on the plaintiff's request for insurance did exist, then the decision of the Court is clearly correct; but if it did not, then it would seem that the only damage which the plaintiff suffered arose purely out of the breach of the preliminary agreement; that therefore the plaintiff should be required to sue in contract; and should not have recovery against both the principal and the agent.

The Chief Justice, in a concurring opinion, relied on the analogy of those cases which hold that a broker is liable if he is instructed to procure insurance for a customer and fails to do so. ${ }^{33}$ (I9I7)

${ }^{23}$ Stearns v. Merchants Life and Casualty Co., 38 N. D. 524 , I65 N. W. 568

${ }^{29}$ Johnson v. Farmers Ins. Co., I84 Towa, 630, I68 N. W. 264 (1918).

${ }^{30}$ Wallace v. Hartford Fire Ins. Co. and Stickfadden, 3I Idaho, 48I, I74 Pac. 1009 (I9I8).

${ }^{31}$ It is submitted that the agent, when he agreed to issue the policy, was acting only in a representative capacity, and did not intend to bind himself. See McCabe v. Aetna Ins. Co., 9 N. D. I9, 8I N. W. 426 (I899). Therefore, he would not be liable to the plaintiff for his principal's failure to perform the contract. Mechen, Agency (2d ed., I914) § I35\%.

${ }^{32} I$. e., a duty arising out of neither statute nor contract.

${ }^{33}$ I8 A. L. R. I2I4 (1922). 
But a broker who is told to procure insurance is thereby made, for the time being, the agent of the customer, to whom he owes a duty to carry out properly his instructions. A representative of an insurance company to whom an application is made, is not the agent of the applicant, but of the company. Whether or not he owes the former a duty to act promptly on the application depends on just the same considerations as whether the company owes any duty to act on the proposal within a reasonable time. Each duty may exist; certain of the cases already considered so hold; but one cannot be inferred by assuming the other. The Chief Justice, when he says that the agent is liable, and that hence the company is also liable, uses as a premise that which it is necessary to prove. Only on the theory that, irrespective of any contract, the agent and the company each owed the plaintiff a duty to issue him a policy or to decline the risk with reasonable speed, can the judgment against both defendants be justified .

The rule of the Duffie case was subjected to a flank attack by the courts of Illinois. In Bradley $v$. Federal Life Insurance Company, ${ }^{34}$ an administrator brought an action against the defendant, whose agent had failed to forward an application for accident insurance made by Fraley, his intestate, with the result that when Fraley, an insurable risk, was killed he was not protected by the policy which, in the normal course of events, would have been issued to him. Neither the Appellate Court nor the Supreme Court passed on the question of whether any duty was owed to the applicant by the company. The former held that whatever right of action the intestate may have had could not pass to his administrator under the laws of Illinois, since it was neither an action to recover damages for an injury to the person or an action to recover damages for an injury to real or personal property. The Supreme Court based its opinion on slightly different grounds, that since the plaintiff's intestate was killed instantaneously, no right of action ever accrued to him, and hence there was no right of action to survive. No separate right of action could accrue to the plaintiff.

\footnotetext{
"Bradley v. Federal Life Insurance Co., 295 I1l. 38I, 127 N. E. I9I (1920), affirming 216 III. App. 602 (1920).
} 
The case raises some interesting problems. The reasoning: of the Supreme Court seems particularly open to question. The fact that Fraley was killed instantaneously would seem to be of little importance. If any duty existed, a thing which the court did not decide, it had been breached before the accident. Fraley should have been allowed to recover nominal damages, if he had sued. The happening of the accident merely increased the quantum of the damages which he, or his administrator, could recover. It is true that no right of action against the insurer sprang into existence after his death. ${ }^{35}$ But the plaintiff was not trying to enforce such a right; the plaintiff was seeking to maintain the right which Fraley had acquired in his own lifetime.

This seems to be the attitude of the Appellate Court. Its decision follows logically from a strict interpretation of the statute providing for the survival of tort actions. ${ }^{36}$ Nevertheless, if the court had felt that a duty clearly should be imposed upon the defendant for reasons of social policy, it would not have stultified itself by holding that the right to recover damages for breach of the duty did not pass to the administrator. In the Duffie case, where the plaintiff was likewise the personal representative of the applicant, the court did not have to treat this phase of the problem, since the right of action clearly survived under the Iowa statute..$^{37}$ Several of the other cases have also passed over the question in silence. $^{38}$ In others where it has been raised, the

${ }^{25}$ The failure to forward the application was not the cause of the death. In any case, there was no statute under which a right of action would accrue to the administrator.

${ }^{38}$ See I11. Rev. Stat. (Cahill, I925), c. 3, § I25:

"In addition to the actions which survive by the common law, the fol-

lowing shall also survive: Actions of replevin, actions to recover damages for an injury to the person (except slander and libel), actions to recover damages for an injury to real or personal property, or for the detention or conversion of personal property, and actions against officers for misfeasance, malfeasance or nonfeasance, of themselves or their deputies, and all actions for fraud or deceit."

At common law an action of tort did not survive the death of the sole plaintiff. I R. C. L. 29; SCHOuler on WILLS, EXECUTORS AND AdNINISTRATORS (6th ed., I923), \& $2 \mathrm{I} 88$.

${ }^{37}$ Iowa, Code (I924), § I0957.

${ }^{28}$ Cf. Carter v. Manhattan Life Ins. Co., supra, note I3; Wallace v. Hartford Fire Ins. Co., supra, note 30; Fox, Admr., v. Volunteer State Life Ins. Co., 185 N. C. I21, I26 S. E. 226 (1923). In all these jurisdictions, statutes provide that the right of action shall not abate, if the cause of action survive. 
court has disposed of it by holding that the action, though sounding in tort, is really based on a breach of duty arising out of an implied contract to decide promptly whether the application will be accepted, ${ }^{39}$ and hence would survive under the common law. Whether the parties do make such an agreement is doubtful. These courts seem to have in mind a duty quasi-contractual in character; that is, a duty which the defendant has not consciously promised to assume, but one to which the courts will nevertheless hold him because they believe that to do so promotes justice and the best interests of society. In substance, it makes no difference whether the court calls the duty one of tort or of quasi-contract; in form, the adoption of the latter label may make it easier to decide that the applicant's right of action passes to his personal representative. It is most important, however, that a tribunal be clear as to whether the obligation is one which the company has voluntarily undertaken, or one which is imposed on it by the law, regardless of its consent. If it is the former, the company can easily escape by inserting a stipulation in the application that no such duty is assumed; if it is the latter, the company's ability to do so is less clear.

Since the Bradley case, decisions in Oklahoma, ${ }^{40}$ North Carolina, ${ }^{41}$ Colorado, ${ }^{42}$ Washington, ${ }^{43}$ and North Dakota, ${ }^{44}$ have

See Haw. Rev. Laws (1915), § 2626; Idaho, Comp. Stat. (I919), §6652; N. C. Cons. Stat. (I919), \& 46I. There are similar provisions in North Dakota, Comp. Laws, Ann (I913), \& 7408; Okla., Rev. Laws (I921), § 223; and Washington, Pierce's Code, \$ 8274. This form of statute leaves open the question of whether the cause of action does survive to the personal representative. In Colorado, however, the statute expressly provides for survival. See Colo. Comp. Laws (Ig2r), \& 5383 .

${ }^{3}$ Columbian Nat. Life Ins. Co. v. Lemmons, 96 Okla. 228, 222 Pac. 255 (1923); Dyer v. Missouri State Life Ins. Co., supra, note 23 .

Security Ins. Co. v. Cameron, 85 Okla. I7I, 205 Pac. I5I (1922) ; Columbian National Life Ins. Co. v. Lemmons, supra, note 39.

12 Fox, Adm'r., v. Volunteer State Life Ins. Co., supra, note 38. Here the agent carelessly failed to deliver the policy which had been issued and sent to him by the home office. The court reversed a judgment of nonsuit. It is not especially clear whether the court believed that the duty to deliver promptly was one imposed by law, or one arising out of an implied contract between the parties. (I924).

DeFord, Adm'r, v. New York Life Ins. Co., 75 Colo. 146, 224 Pac. 1049

"Dyer v. Missouri State Life Ins. Co., supra, note 23.

"A lower court case, for the statement of which see In re Coughlin's Estate, 205 N. W. I4 (N. D., I925). The administratrix sued in tort, 
reld that a duty to act promptly existed. ${ }^{45}$ The opinions in these cases have not added greatly to the reasoning in support of the rule, for they have relied largely on the earlier authorities. But their number, coupled with the fact that there have been no decisions denying the existence of the duty, firmly establishes the doctrine of Boyer v. State Farmers Mutual Hail Insurance Co. and of Duffie v. Bankers Life Insurance Co. in the insurance law of this country.

Considering the problem purely on its merits, it is submitted that the rule announced by those cases is a desirable one. Insurance has come to play such an extensive part in our civilization that the business is recognized as being quasi-public in character; and the insurance contract is treated by the courts in a way different from ordinary agreements. More and more the tendency seems to be to shift wherever possible the burden of loss due to accident or catastrophe from the shoulders of the individual to those of the community or of a group within the community. While this policy is usually effected by legislation, ${ }^{46}$ the courts have also been ready to further it in their treatment of the rules of the common law. ${ }^{47}$ In the particular situation which has been considered, where carelessness on the part of the insurer has resulted in the unfortunate applicant being left unprotected by the insurance which, but for that carelessness, he would have obtained; it is rather natural for the courts to hold that the burden of the loss which the applicant suffered must be assumed by the insurer, $i . e$. , the group.

It must be remembered that the insurer is usually receiving a premium during the time when it is holding the application in abey-

and secured a verdict and judgment. No appeal was taken. Later the defendant moved for judgment $\boldsymbol{n}$. $o$. $v$. or for a new trial. This motion was denied because made too late. On appeal the order denying the motion was affirmed. Coughlin v. Aetna Life Ins. Co., 49 N. D. 948, 194 N. W. 66r (1923).

${ }^{15}$ The Supreme Court of Wyoming sustained a verdict directed for the defendant on the ground of the insufficiency of the plaintiff's evidence, but refused to pass on the questions of whether any duty existed and whether the cause of action would survive. Dunne v. Western National Life Ins. Co., 246 Pac. 246 (Wyo., 1926).

${ }^{16}$ For example, by workmen's compensation statutes.

${ }^{17}$ In the many decisions favoring the insured, courts have undoubtedly been influenced by a desire to spread the loss. 
ance. Furthermore, it is seldom subjected to greater liability than it would have incurred had it functioned properly and accepted the proposal. 48 To allow it to benefit as the result of its carelessness, which has so greatly harmed the applicant, seems offensive to all theories of justice. That this attitude will not be shared by all persons who will confront the problem is readily admitted; and the desirability of imposing on the insurer the duty to act promptly will never be demonstrated with mathematical exactitude. It is believed, however, that when the question is presented before the appellate tribunals of the various states of this country which have not yet considered it, the majority of them will be sufficiently influenced by the considerations which have been mentioned to decide that the insurer must be responsible for the loss which the applicant incurred.

On what ground will they rest their decisions? Probably none will take the position that the company is liable on the completed contract of insurance, in that the silence of the insurer constituted an acceptance of the offer in the application. While there may be situations when silence is an acceptance, this is not one of them. ${ }^{49}$ The authorities are too numerous for the courts to disregard. ${ }^{50}$ Nor should the courts resort to estoppel, that haven of refuge of the perplexed jurist. It is doubtful whether, under our objective theory of contract, estoppel can play any part. ${ }^{51}$ In any case, there is no real estoppel here; as many of the early cases pointed out, the ordinary man would not infer from the silence of the insurer that his proposal had been approved. If he thought of the matter at all, he would surely con-

is The proper measure of damages in a tort action would be the amount of the policy applied for, less the premium which would have been paid. This sum is precisely what the company would have lost had it accepted the risk. Of course, if the risk was such that not only the defendant, but any other company would have declined it, the plaintiff has not been injured by the delay.

- On silence as assent to an offer, see Wirliston, Contracts (I920), \&.9r; and Corbin, Offer and Acceptance, and Some of the Resulting Legal Relations, 26 Y ALE L. J. 169 (1917). The latter points out that while the offeror may, perhaps, confer a power on the offeree to make silence operate as an acceptance, he cannot unreasonably deprive the offeree of his pre-existing immunity in keeping silent. See pp. 200, 20I.

${ }^{\infty}$ See citations, supra.

${ }^{31}$ See 33 HaRv. L. REv. 595 (I920). 
clude that some question had been raised by the home office, and that no policy had yet been issued to him.

The suggestion that the insurer or the agent promises to act promptly ignores actuality. No such agreement is made expressly, nor can the intention to make one be implied. If a court should hold that a contract to decide expeditiously on the proposal did exist, it is believed that, within a short time, all insurance companies doing business in that jurisdiction would incorporate in their applications stipulations expressly negativing any such promise.

The only remaining ground, then, is to hold that the insurer is under a duty entirely irrespective of contract, one which the law imposes regardless of the company's desire to assume it. Whether this duty be called one of tort or of quasi-contract is immaterial. In either case, its fundamental feature is its nonconsensual nature. It is a duty peculiar to the business of insurance, and does not extend beyond it. It is believed that theordinary business man will never be subjected to a similar obligation. ${ }^{\mathbf{2 2}}$

One problem commands attention. Granting the existence of the duty, to whom is it owed? When a man applies for a policy of life insurance, naming $X$ beneficiary, who is the proper party to sue the insurer? The decisions are unanimous in holding that the estate of the applicant and not the named beneficiary should recover. This may produce most unjust results. If the estate is heavily indebted, the entire proceeds of the judgment may go to the creditors and $\mathrm{X}$ may take nothing; whereas, if the policy had actually been issued, $\mathrm{X}$, if protected by exemption laws,

\footnotetext{
${ }^{52}$ Only two cases similar to those discussed have been found outside the field of insurance law. In Four States Grocery Co. v. Wickendon, 217 S. W. II03 (Tex. Civ. App., I9I9), the agent of the defendant, a mercantile corporation, took an order from the plaintiff, which he failed to send in for acceptance. As a result, the plaintiff never secured the goods, and was forced to purchase them elsewhere at a higher price. He sued the defendant, on the contract to purchase, and alleging that the defendant was estopped to deny the making of the contract because of the negligence of the salesman and his reliance on the sending in of the ordèr. Judgment was rendered for the defendant. See comment by Charles E. Clark, 29 Y Ale L. J. 673 (I920). Cf. Cole-McIntyre-Norfleet Co. v. Holloway, supra, note Io, where under similar circumstances, the defendant was held liable on the contract. See comments 29 Y ALE L. J. 44I (I920); 33 HARv. L. REv. 595 ( 1920 ).
} 
would have received the entire sum. ${ }^{53}$ Again, if $\mathrm{X}$ is a person not related to the deceased, and not named as legatee in his will, he will be entitled to nothing, and whatever is recovered will go to swell the estate. Indeed, it is difficult to see how, in such a situation, the estate could recover anything more than nominal damages; true, the insurer owed the applicant a duty, but the breach of that duty injured neither the applicant nor his estate, but only $X$. The latter should be the one to sue and recover. It may be objected that the law will not ordinarily award damages for itijuries to mere expectancies. ${ }^{54}$ But it will do so in a few situations, ${ }^{55}$ and despite the dearth of precedent, it is believed that it should do so here. The situation is not unlike that found when a donee berieficiary seeks to recover for breach of contract, and the same comment is applicable: that any sensible system of law will also allow him relief. ${ }^{56}$

Undoubtedly, insurance companies will attempt to relieve thiemselves of this duty, by stipulations in their applications to the effect that they shall have a given number of days within which to consider the proposal, after which time, if the applicant has heard nothing, his offer shall be deemed rejected. ${ }^{57}$ It is believed that such a term will not fully protect the insurers in any jurisdiction which holds that a duty to act promptly exists. Where the duty is imposed by statute, courts have decided that it could not be avoided. ${ }^{58}$ Even if the duty is non-statutory, the same result should follow. Just as a carrier cannot by contract escape liability for its negligence, so an insurance company should be held

"In Coughlin's Estate, supra, note 44, the wife recovered as administratrix, and the creditors claimed the proceeds of the judgment. The court decided, however, that they were exempt, under N. D. Comp. Laws Ann. (1913), \& 8719, providing that the avails of a life insurance policy, payable to the estate of the deceased, should not be subject to the debts of the decedent. In many other states, where the exemption laws are less liberal, the creditors would have succeeded.

"See 27 Yale L. J. 263 (I9I7); 28 Yale L. J. 507 (I9I9).

${ }^{2}$ Cf. Metallic Compression Casting Co. v. Fitchburg R. Co., 109 Mass. 277 (1872); Lewis v. Corbin, I95 Mass. 520, 81 N. E. 248 (1907); Concordia Fire Ins. Co. v. Simmons County, 167 Wis. 54I, 168 N. W. 199 (1918).

${ }^{3} C f$. Winliston, Contracts (19z0), § 357 .

${ }^{57} \mathrm{Cf}$. the clause suggested by Mr. Jones, in his article cited, supra, note 2.

"Wanberg v. Nat. Union Fire Ins. Co., supra, note 18; National Union Fire Ins. Co. v. Wanberg, supra, note Ig. 
responsible if the carelessness of its agent leaves the applicant unprotected. If it can be shown that within the given period, the company could have acted but failed to do so, it has violated its duty to the applicant, and must answer to him for whatever damages he suffers thereby. However, such a stipulation may have one effect: after the expiration of the period it may cast on the applicant the obligation to seek insurance elsewhere. The gist of the tort action is the failure of the insurer to decide or to inform the applicant of its decision, thereby preventing him from securing protection from another company. The insurer may reject his proposal for any cause whatever. After the expiration of the given period, therefore, it would seem that the situation was just as if the insurer had, on the last day, informed the applicant that it declined to accept the risk. Such a stipulation would, therefore, decrease the number of instances in which the insurer might be liable, but would not relieve it of responsibility in every case.

Undoubtedly this battle between the company and the disappointed applicant will be carried on in other jurisdictions. Probably each side will win some victories. But it is believed that if a survey be made in years hence, it will be found that the insurer, in the majority of instances, will have been required to answer in damages for its negligent delay.

Carl W. Funk.

Philadelphia, $P a$. 